\title{
Hypoglycemic and Antianemia Effects of Chlorophyll from Sauropus androgynus (L) Merr Leaves in Rats
}

\author{
Suparmi Suparmi ${ }^{1} *$, Minidian Fasitasari ${ }^{2,3}$, Martanto Martosupono ${ }^{4}$, Jubhar Christian Mangimbulude ${ }^{4}$
}

Suparmi Suparmi ${ }^{1, *}$, Minidian

Fasitasari ${ }^{2,3}$, Martanto

Martosupono ${ }^{4}$, Jubhar Christian Mangimbulude ${ }^{4}$

'Department of Biology, Faculty of Medicine, Universitas Islam Sultan Agung, Semarang 50112, INDONESIA.

${ }^{2}$ Department of Clinical Nutrition, Faculty of Medicine, Universitas Islam Sultan Agung, Semarang 50112, INDONESIA.

${ }^{3}$ Sultan Agung Islamic Hospital, Semarang 50112, INDONESIA.

${ }^{4}$ Master Program of Biology, Satya Wacana

Christian University, Jl. Diponegoro 52-60

Salatiga 50711, INDONESIA.

\section{Correspondence}

\section{Suparmi Suparm}

Department of Biology, Faculty of

Medicine, Universitas Islam Sultan Agung

JI. Raya Kaligawe Km 4 Semarang 50112

INDONESIA.

Phone no: +62 24 6583584; +62 24

6582455

E-mail: suparmi@unissula.ac.id

History

- Submission Date: 20-03-2021;

- Review completed: 19-04-2021;

- Accepted Date: 05-05-2021.

DOI : 10.5530/pj.2021.13.119

Article Available online

http://www.phcogj.com/v13/i4

\section{Copyright}

(C) 2021 Phcogj.Com. This is an open access article distributed under the terms of the Creative Commons Attribution 4.0 International license.

\section{ABSTRACT}

Background: Beneficial effect of katuk (Sauropus androgynus L Merr) leaves (CSA) as one of medicinal plant in Indonesian jamu may potential to cure diabetes mellitus (DM) and iron deficiency anemia (IDA) as well as its well-known effect to increase breast milk production. Objectives: This study was aiming to explore the hypoglycemic effects of CSA in streptozotocininduced DM rats (STZ) and antianemia effects in IDA rats (FeD). Material and Methods: STZ male Wistar rats were treated with CSA, commercial chlorophyll (ChIn) and glibencamide. Blood glucose levels and histological changes of liver, kidney and pancreas were analyzed after 14 days treatment. At separate experiment, FeD female Wistar rats were treated with CSA and Chln. The treatment was performed orally at the $1^{\text {st }}-20^{\text {th }}$ day of pregnancy. Levels of $\mathrm{Hb}$, Fe and ferritin blood serum, number and body weight of the offspring were analyzed on $21^{\text {st }}$ day (post-partum). Results: Treatment of CSA for 14 days to diabetic animals demonstrated the hypoglycemic effect, however the histological analysis suggested that the scores of liver, kidney and pancreas were higher than that in the normal group. Moreover, CSA exerted a significant restorative effect by returning the levels of hemoglobin, serum iron, and serum ferritin. A fetus analysis suggested that the fetus body weight of in the CSA and ChIn groups was similar to that in the normal group. Conclusion: CSA treatment are potential as a new herbal supplement to cure DM and IDA. However, the safety dose should be considered to prevent the toxicity.

Key words: Antioxidants, Chlorophyll, Diabetes mellitus (DM), Iron deficiency anemia (IDA), Sauropus androgynus (L) Merr.

\section{INTRODUCTION}

Diabetes mellitus (DM) is a carbohydrate metabolic disease characterized by chronic high blood glucose, which leads over time to serious damage to the heart, blood vessels, eyes, kidneys and nerves. Globally, about 422 million people have DM, which resulted 1.6 million deaths in 2015. ${ }^{1}$ Based on the report of Basic Health Research (Riskesdas) 2018 from Ministry of Health Republic of Indonesia, the prevalence of DM in Indonesia was $1.5 \%$ of the general population. ${ }^{2}$ Several reports have indicated that anemia is one of the commonest blood-related disorders seen in DM patients with poorly glycemic control, ${ }^{3,4}$ therefore regular screening for anemia in all DM patients may help in the early detection and management of anemia.

Anemia is characterized by a diminished erythrocyte mass or reduction in the hemoglobin $\mathrm{Hb}$ concentration of blood, which causes deficiency in the oxygen-carrying capacity of blood. ${ }^{5}$ WHO (2020) reported that $42 \%$ of children less than 5 years of age and $40 \%$ of pregnant women worldwide are anemic. ${ }^{6}$ Riskesdas 2018 reported that stated that, $48.9 \%$ of pregnant women in Indonesia had anemia, which particularly caused by iron deficiency. ${ }^{2,7}$ Iron deficiency anemia (IDA) during pregnancy is associated with increased adverse reproductive outcomes, including preterm delivery, low-birth-weight infants, and decreased iron stores for the baby, which may lead to impaired development. ${ }^{5,7,8}$

Natural compounds in herbal medicines are reported as a food-based strategies can be addressed to prevent and treat DM and IDA.9.10 Katuk (Sauropus androgynus L Merr) leaves is one of medicinal plant in Indonesian jamu which is commonly used to increase milk production, as an antipyretic, consumed as a vegetable and used as a colorant. ${ }^{11,12}$ The beneficial effects of antioxidative components of SA leaves have been proven in vitro and in vivo studies, although there is also reported some adverse health effects of intake the fresh SA leaves like bronchiolitis obliterans. ${ }^{13-16}$ A study by Sai and Srividya $(2002)^{17}$ showed the hypoglycemic activity of aqueous SA leaf digest in human. Our previous study reported that antioxidant activity of chlorophyll extract from katuk leaves (CSA) showed the potential effect to cure sodium nitrate-induced anemia in female mice ${ }^{18}$ and female Wistar rats ${ }^{19}$. However, the beneficial effects of chlorophyll from SA leaves to cure DM and IDA and its precautious use have not investigated yet.

The aim of present study was to investigate the hypoglycemic effects of CSA on reducing blood glucose levels in streptozotocin-induced DM rats and antianemia effects in iron deficiency anemia (IDA) rats. Using a commercial chlorophyll (Chln) as comparison, we could analysis the potency of CSA to cure diabetes mellitus (DM) and IDA. The present 
study attempted to evaluate the toxicity of CSA as antidiabetic herbal supplement by analyzing the histopathologic changes of liver, kidney and pancreas. In addition, the number of fetus and its body weight delivered by IDA rats were analyzed to examine the risk effect of using CSA as antianemia herbal supplement for pregnant woman. This study will provide important information concerning the exploration of plant pigment as herbal supplement to cure DM and IDA.

\section{MATERIALS AND METHODS}

\section{Extraction preparation}

Fresh leaves of S. androgynus (L) Merr (SA) were collected from the inhabitant park in Penggaron Lor Village, Genuk, Semarang, Central Java, Indonesia. The chlorophyll extract of SA leaves was obtained by an extraction methods using acetone: methanol $(7: 3, \mathrm{v} / \mathrm{v})$ as described in our previous research. ${ }^{18,19}$ As comparation, we used the commercial chlorophyll, K-Liquid ${ }^{\mathrm{TM}}$ purchased from a drug store in Semarang, Central Java, Indonesia. The chlorophyll extract of SA and the commercial chlorophyll were dissolved in distilled water as treatment solution, CSA and ChLn, respectively.

\section{Experimental animals}

Wistar rats of age 2-3 months with body weight 150-200 g were purchased from Laboratorium Penelitian dan Pengujian Terpadu, Gadjah Mada University, Indonesia. The rats were properly housed in standard hard bottom polypropylene cages in climate- and accesscontrolled rooms $\left(23^{\circ} \mathrm{C} \pm 2^{\circ} \mathrm{C}, 0 \% \pm 4 \%\right.$ humidity, $12 \mathrm{~h}$ light $/ 12 \mathrm{~h}$ dark cycle). Food and water were available ad libitum. Ethical clearance No. 150/V/2015/Komisi Bioetika was obtained from the Ethics Committee of the Faculty of Medicine, Universitas Islam Sultan Agung, Indonesia. All rats were acclimatized for 1 weeks prior to the commencement of the experiments.

Assessment the hypoglycemic effect of CSA on streptozotocin-induced diabetes mellitus (DM) rats

\section{Study design}

The first part of our study was aiming to evaluate the beneficial and toxicological effects of CSA as an antidiabetic herbal supplement in streptozotocin-induced DM rats. Twenty-five male Wistar rats were randomly divided into 5 groups Wistar rats, comprising 5 rats per group. Healthy rats were used as control group (N). Induction of diabetes was performed by intravenous injection of streptozotocin (20 $\mathrm{mg} / \mathrm{kg}$ bw; Sigma, USA) dissolved in citrate buffer (10 mM, pH 4.5, final volume $0.1 \mathrm{~mL} / 100 \mathrm{~g} \mathrm{bw}$ ) after overnight fasting for 5 days. The confirmation of the diabetes was made 14 days later by checking the fasting glycemia and recognized as pre-treatment blood glucose level. The streptozotocin-induced diabetic rats were randomly allocated to one of the following groups: untreated streptozotocin-induced rats (STZ); diabetic animals treated with chlorophyll extract from $S$. androgynus (L) Merr leaves at dose $0.016 \mathrm{mg} / \mathrm{mL}$ (STZ+CSA); diabetic rats treated with commercial chlorophyll at dose $0.016 \mathrm{mg} / \mathrm{mL}$ (STZ+ Chln); and diabetic rats treated with glibenclamide $0,09 \mathrm{mg} / 200 \mathrm{~g} \mathrm{BW}$ (STZ+Gib). The treatment solutions were orally gavaged $3.6 \mathrm{~mL} / 200 \mathrm{~g}$ BW/day for 14 days.

\section{Analysis of blood glucose level}

Blood samples were collected from the animals via the periorbital sinus $24 \mathrm{~h}$ after the last treatment. About $1.5 \mathrm{ml}$ of the blood was allowed to clot at room temperature. The clotted blood samples were centrifuged at $3000 \mathrm{rpm}$ for $10 \mathrm{~min}$ to obtain the serum, which was used for blood glucose analyses. The blood glucose levels of pre-treatment and after 14 days treatment (post-treatment) were measured using enzymaticcolorimetric-end point.

\section{Histological assessment of pancreas, liver and kidney}

All the animals were then sacrificed by anesthetizing with diethyl ether $24 \mathrm{~h}$ after the last treatment. The liver, kidney and pancreas samples were collected in 10\% formalin for histological analysis. The organ tissues were processed and embedded in paraffin wax and sections were made of about 4-6 $\mu \mathrm{m}$. Replicate sections were stained with hematoxylin and eosin ( $\mathrm{H} \& \mathrm{E})$ for evaluation of histological changes under the microscope (Olympus, Japan) and photographed. The organ slides preparation and result interpretation were done by a pathologist at Department of Anatomical Pathology, Gadjah Mada University, Yogyakarta, Indonesia.

Organ scores were used to evaluate the safety of CSA supplementation in DM. ${ }^{20}$ The scores, 0-4 were used to grade the histological changes of the liver, kidney and pancreas of rats in different groups. The higher score indicated the hypertrophy or necrosis of the organ. ${ }^{21-23}$

\section{Assessment the antianemia effect of CSA on iron deficiency anemia (IDA) rats}

\section{Study design}

The goal of the second part of our study was to evaluate the beneficial and toxicological effects of CSA as antianemia on the IDA female rats. Twenty-four female rats were divided into 4 groups: a control group which was fed with a standard diet $(\mathrm{N})$, an anemia model group (FeD); $\mathrm{FeD}$ treated with CSA $(\mathrm{FeD}+\mathrm{CSA}) ; \mathrm{FeD}$ treated with Chln $(\mathrm{FeD}+$ Chln). An anemia model group was established by feeding rats with an iron-deficient diet for 14 days. The day of 15 anemia-induced female rats were then mated with 2 male rats per group to allow the pregnancy. Female rats that were pregnant since day 0 received the same treatment as in their respective groups. The treatment of CSA of $0.016 \mathrm{mg} / \mathrm{mL}$ and Chln of $0.016 \mathrm{mg} / \mathrm{mL}$ was performed orally as $3.6 \mathrm{~mL} / 200 \mathrm{~g} \mathrm{BW/}$ day at the $1^{\text {st }}$ until $21^{\text {st }}$ pregnancy of $\mathrm{FeD}+\mathrm{CSA}$ and $\mathrm{FeD}+\mathrm{Chln}$ groups, respectively. The $\mathrm{N}$ and $\mathrm{FeD}$ were treated with distilled water at the same volume.

\section{Assessment of body weight, and blood biochemical parameter for anemia rat's post-partum}

The body weight was monitored before the treatment, day $0,7,20$ of pregnancy and day 21 post-partum. On the $21^{\text {st }}$ day (post-partum) blood was taken from the arteries in the orbital sinus of the eye and then measured the levels of hemoglobin $(\mathrm{Hb})$, serum iron and serum ferritin. $\mathrm{Hb}$ levels were measured using the photometric method with the DiaSys kit. Serum iron levels were measured using the nitropaps colorimetric test method (DiaSys Kit), while ferritin levels were measured using the Immunological method, Particle Enhanced Turbimetric. The number of fetus, and its body weight were measured on the first day of birth.

\section{Statistical analyses}

All results were expressed as mean values \pm SEM. Comparisons between multiple groups were analyzed by one-way ANOVA followed by a post hoc Tukey test using IBM SPSS 25 . If the data were not normally distributed, we used the Kruskal-Wallis test (nonparametric ANOVA) followed by Mann Whitney test. Statistically, $p<0.05$ was considered significant.

\section{RESULTS}

\section{Hypoglycemic effect of CSA in STZ-induced DM rats}

To find the effectivity of CSA on the reduction of blood glucose levels, streptozotocin-induced diabetic rats were treated with CSA, commercial chlorophyll (Chln) and glibencamide. In untreated streptozotocin-induced DM (STZ), a slight reduction of blood glucose 
level persisted during 4 weeks after the injection (Figure 1). The induction of STZ caused a significant higher score of liver and kidney compared to normal rats (Table 1). As a positive control, diabetic rats were treated with glibenclamide, the most widely use antidiabetic drugs. This treatment caused substantial reduction in blood glucose levels in STZ-induced DM (Figure 1) and showed significantly less degeneration score of hepatocytes, proximal tubule epithelium and pancreatic cells (Table 1).

After treated with CSA and Chln, glucose blood level was reduced $22.64 \pm 3.20$ and $28.96 \pm 5.44 \mathrm{mg} / \mathrm{dL}$, respectively (Figure 1). The reduction of CSA was not significantly differed with the group treated with Chln, indicating that CSA is as potential as commercial marketed chlorophyll, Chln. The effect of CSA was significantly different with the positive control $(\mathrm{STZ}+\mathrm{Gib})$, showing that the CSA is less effective than glibenclamide. These findings were confirmed by the histological assessment (Table 1 and Figure 2). CSA treated STZ-induced diabetic rats (STZ+CSA) showed parenchymatous degeneration of all hepatocytes with score $2.12 \pm 0.08$, which was significantly difference with normal rats $(\mathrm{N})$. The treatment caused a lesion of kidney proximal tubule epithelium cells with score $1.28 \pm 0.12$, which was not significantly different with STZ. The CSA treated DM animals showed a severe insulitis, with score $1.16 \pm 0.17$ in which this value was significantly different with normal rats $(\mathrm{N})$.

\section{Antianemia effect of CSA on iron deficiency anemia (IDA) rats}

In separate experiments, we evaluated the antianemia effect of CSA and its toxicological effects in IDA rats. In comparison with the normal group, the hemoglobin level of the rats in the IDA group (FeD, Fed+CSA, and $\mathrm{FeD}+\mathrm{Chln}$ rats) displayed a significant decreased $(p<0.05)$ after feeding with the low-iron diet for 14 days (Figure 3$)$. At the end of the anemia inducing process, the rats were treated with CSA or Chln for another 14 days.

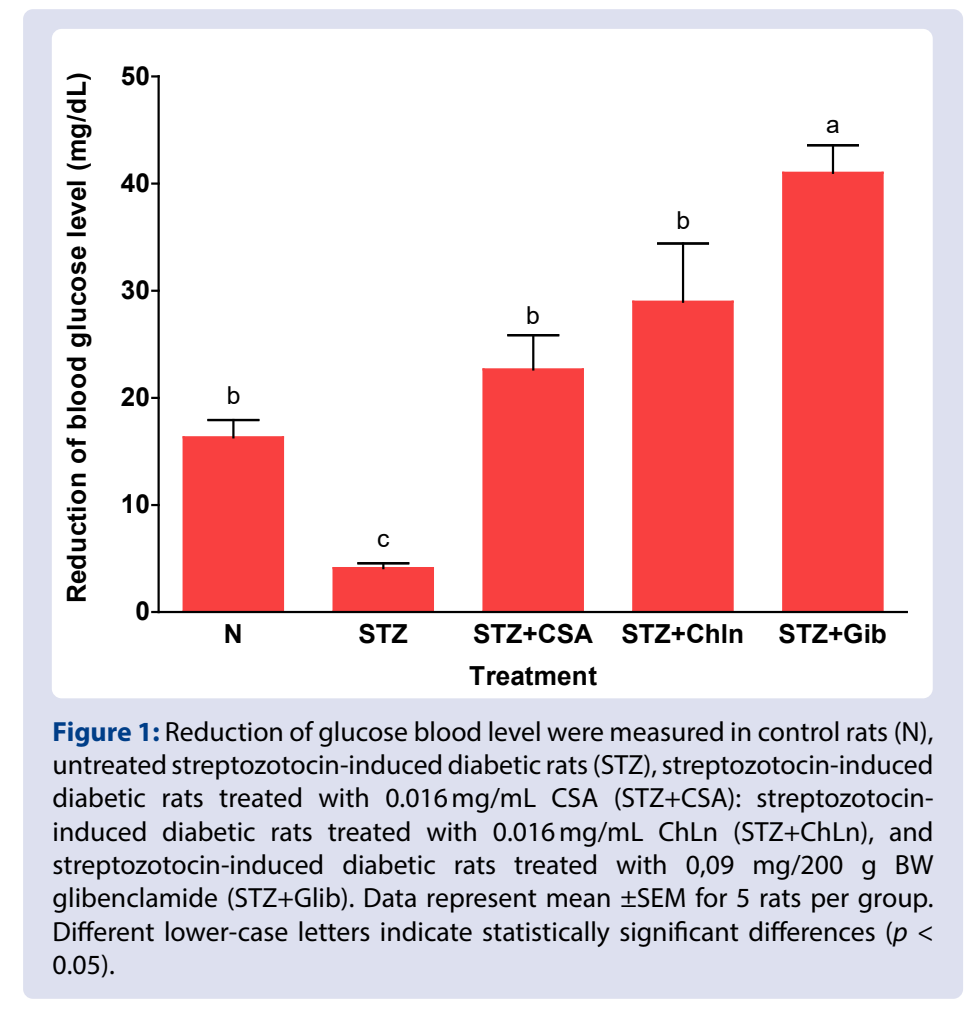

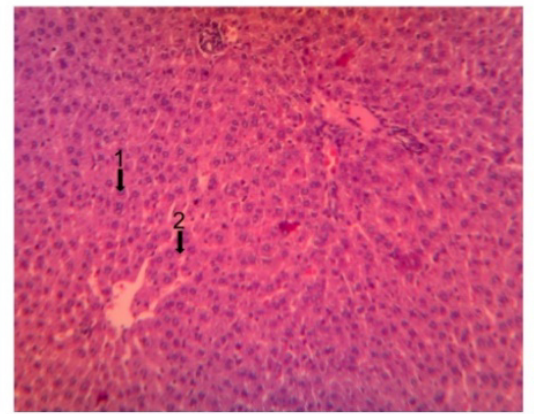

(a)

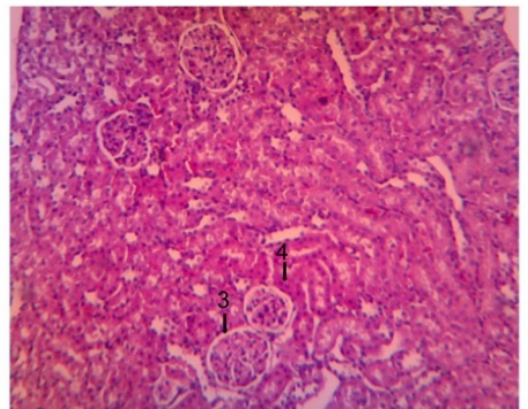

(b)

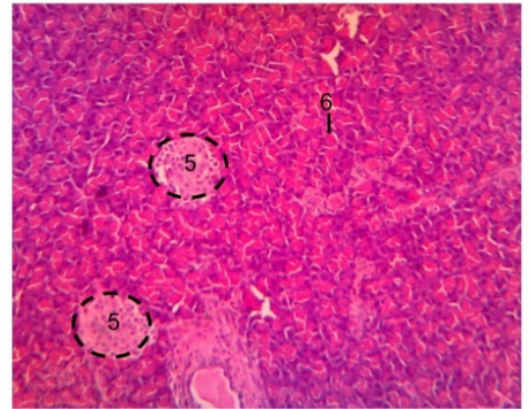

(c)

Figure 2: Representative microscopic tissue images of streptozotozin-induced diabetic rats treated with chlorophyll extract from Sauropus androgynus leaves (STZ+CSA) (H\&E), (a) lover (arrow $1=$ hepatocytes, $2=$ sinusoid), (b) kidney (arrow $3=$ glomerular capsule, $4=$ papillary ducts), and (c) pancreas (circle $5=$ islet of Langerhans, arrow $6=$ acinus). Photographs were obtained by light microscopy at $400 \times$ magnification. 


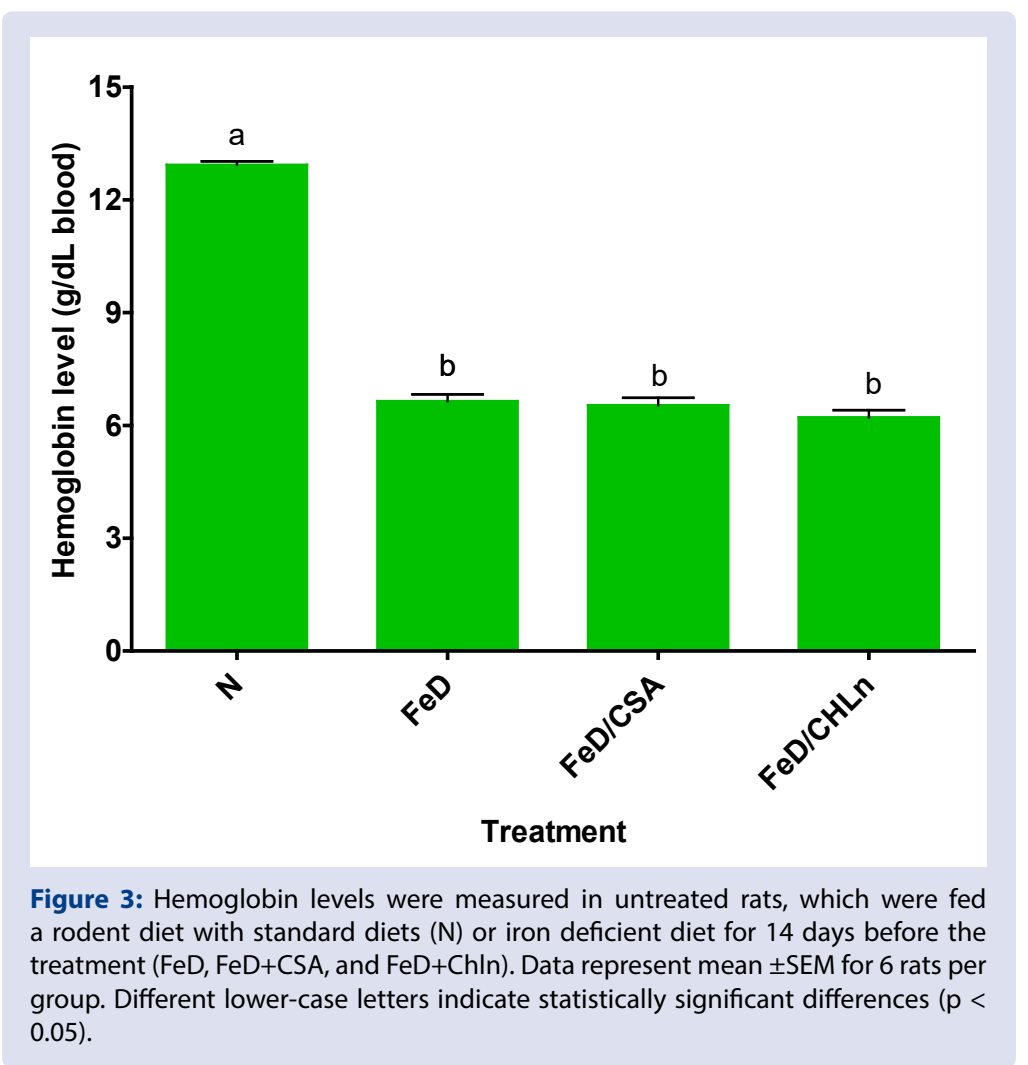

Table 1: Histological changes in liver, kidney and pancreas.

\begin{tabular}{|c|c|c|c|}
\hline \multirow{2}{*}{ Groups } & \multicolumn{3}{|c|}{ Histological score } \\
\hline & Liver & Kidney & Pancreas \\
\hline $\mathrm{N}$ & $1.25 \pm 0.25^{\mathrm{b}}$ & $1.00 \pm 0.00^{\mathrm{b}}$ & $0.00 \pm 0.00^{c}$ \\
\hline STZ & $2.48 \pm 0.29^{\mathrm{a}}$ & $1.64 \pm 0.17^{\mathrm{a}}$ & $0.00 \pm 0.00^{c}$ \\
\hline STZ+CSA & $2.12 \pm 0.08^{\mathrm{a}}$ & $1.28 \pm 0.12^{\mathrm{a}, \mathrm{b}}$ & $1.16 \pm 0.17^{a}$ \\
\hline STZ+Chln & $2.25 \pm 0.48^{\mathrm{a}}$ & $1.10 \pm 0.10^{\mathrm{b}}$ & $0.40 \pm 0.40^{\mathrm{a}, \mathrm{b}}$ \\
\hline STZ+Glib & $1.33 \pm 0.33^{\mathrm{b}}$ & $1.07 \pm 0.07^{\mathrm{b}}$ & $0.67 \pm 0.33^{\mathrm{a}, \mathrm{b}}$ \\
\hline
\end{tabular}

Note: $\mathrm{N}$ was normal rats. Animals were induced with $20 \mathrm{mg} / \mathrm{kg}$ bw streptozotocin (STZ) after overnight fasting for 5 days. Then 2 week later, all animals received $0.016 \mathrm{mg} / \mathrm{mL}$ CSA (STZ+CSA); $0.016 \mathrm{mg} / \mathrm{mL}$ Chln $(\mathrm{STZ}+\mathrm{Chln})$, and 0,09 $\mathrm{mg} / 200 \mathrm{~g}$ BB glibenclamide (STZ+Glib) for $14 \mathrm{days}$. Data represent means \pm SE of $\mathrm{n}=5$ animals per group. Different lower-case roman letters in the same column indicate a significant between different groups $(p<0.05)$.

We hypothesized that CSA might be effective for treatment of Fedeficiency anemia in pregnant woman and the baby delivered, therefore after treatment with CSA and Chln the animals were mated until pregnant. After the delivery process on day- 21 the rats were sacrificed to analyze the level of $\mathrm{Hb}$, serum iron and serum ferritin after the treatment. Supplementation with CSA and Chln enhanced $\mathrm{Hb}$, serum iron and serum ferritin compared to untreated IDA animals (FeD) (Table 2). The increasing of $180.25 \%$ in $\mathrm{Hb}$ levels after CSA and of $170.06 \%$ after Chln was no significant different between the $\mathrm{Hb}$ levels indicating the CSA is effective as commercial Chln to cure IDA. Considering the enhancement of levels of serum iron and serum ferritin, CSA was more effective in preventing Fe deficiency anemia than Chln (Table 2).

IDA is considered as a complex condition which affects growth and development ${ }^{8,24}$ thus in this study we measured the body weight at different time intervals. As shown at Figure 4, at the pre-treatment the body weight of rats in all groups displayed no significant difference $(p$ $>0.05$ ). Treatment of anemia animals with $0.016 \mathrm{mg} / \mathrm{mL}$ CSA did not affected the body weight of animal during the pregnancy of $0,7,14$ days and after delivery, although the body weight of the CSA-treated anemia rats were significantly different compare to control at the end (day 20) of pregnancy (Figure 4). These findings were confirmed by the number and body weight of offspring (Table 3). Treated anemic animals with CSA showed the significant increase of significance difference on number of offspring and its body weight compare to untreated anemic group (FeD). The average of offspring body weight anemic animals on the Chln had similar with the normal animals.

\section{DISCUSSION}

Nowadays, the increasing of DM incidence become a major public concern considering its several complications, including anemia, retinopathy, nephropathy and nephropathy. ${ }^{3,25,26}$ The complications are affecting longevity and life quality thus an effort to explore a safe herbal supplement is needed to control the hyperglycemia in DM patient. The present study has thus, indicated that the chlorophyll from Sauropus androgynus (L) Merr (CSA) have a good potential for lowering blood glucose levels in diabetic rats.

The induction of streptozotocin (STZ) provoked a mild DM in rats as indicated by a significant increasing of blood glucose levels. Moreover, the STZ-induced DM rats showed increase in the histological score of liver and kidney damage, which are reported as a first symptom of hyperglycemia caused by progressive alteration of oxidative stress. ${ }^{27-29}$ Our study showed that there was no insulitis of pancreatic cells in STZ 
Table 2: Effect of CSA on the levels of $\mathrm{Hb}$, serum iron and serum ferritin.

\begin{tabular}{cccc}
\hline & & \multicolumn{2}{c}{ Levels } \\
\cline { 2 - 4 } Groups & $\mathrm{Hb}(\mathrm{mg} / \mathrm{dL})$ & Serum iron $(\mu \mathrm{g} / \mathrm{dL})$ & Serum ferritin $(\mu \mathrm{g} / \mathrm{dL})$ \\
\hline $\mathrm{N}$ & $12.73 \pm 0.07^{\mathrm{a}}$ & $64.43 \pm 0.62^{\mathrm{a}}$ & $119.94 \pm 1.37^{\mathrm{a}}$ \\
FeD & $6.38 \pm 0.14^{\mathrm{c}}$ & $24.38 \pm 1.4^{\mathrm{c}}$ & $44.64 \pm 1.88^{\mathrm{d}}$ \\
FeD+CSA & $11.50 \pm 0.24^{\mathrm{b}}$ & $61.46 \pm 1.75^{\mathrm{a}}$ & $103.14 \pm 1.55^{\mathrm{b}}$ \\
\end{tabular}

Note: Animals were fed an iron deficiency diet (FeD) or a standard diet $(\mathrm{N})$ for 2 weeks. Then all animals received $0.016 \mathrm{mg} / \mathrm{mL} \mathrm{CSA}(\mathrm{Fed}+\mathrm{CSA}) ; 0.016 \mathrm{mg} / \mathrm{mL} \mathrm{Chln}$ $(\mathrm{FeD}+\mathrm{Chln})$ for 14 days and were mated then sacrificed 21 days later (after delivery their offspring). Hb, Fe and Ferritin levels were measured as indicators of anemia. Data represent means $\pm S E$ of $n=6$ animals per group. Different lower-case roman letters in the same column indicate a significant between different groups $(p<0.05)$.

Table 3: The number and the body weight of offspring's delivered in each experimental group.

\begin{tabular}{|c|c|c|}
\hline \multirow{2}{*}{ Groups } & \multicolumn{2}{|c|}{ Parameters } \\
\hline & Number of offspring's & Body weight of offspring's \\
\hline $\mathrm{N}$ & $12.00 \pm 0.32^{\mathrm{a}}$ & $5.64 \pm 0.02^{\mathrm{a}}$ \\
\hline $\mathrm{FeD}$ & $8.33 \pm 0.2^{c}$ & $3.18 \pm 0.04^{c}$ \\
\hline $\mathrm{FeD}+\mathrm{CSA}$ & $9.50 \pm 0.22^{\mathrm{b}}$ & $5.36 \pm 0.03^{b}$ \\
\hline $\mathrm{FeD}+\mathrm{Chln}$ & $9.83 \pm 0.30^{\mathrm{b}}$ & $5.56 \pm 0.02^{\mathrm{a}}$ \\
\hline
\end{tabular}

Note: Animals were fed a Fe-deficiency diet (FeD) or a standard diet (N) for 2 weeks. Then all animals received $0.016 \mathrm{mg} / \mathrm{mL} \mathrm{CSA}(\mathrm{Fed}+\mathrm{CSA}) ; 0.016 \mathrm{mg} / \mathrm{mL} \mathrm{Chln}$ $(\mathrm{FeD}+\mathrm{Chln}$ ) for 2 weeks and were mated and sacrificed 21 days later (after delivery their offspring). $\mathrm{Hb}$, Fe and Ferritin levels were measured as indicators of anemia. Data represent means $\pm S E$ of $n=6$ animals per group. Different lower-case roman letters in the same column indicate a significant between different groups $(p<0.05)$.

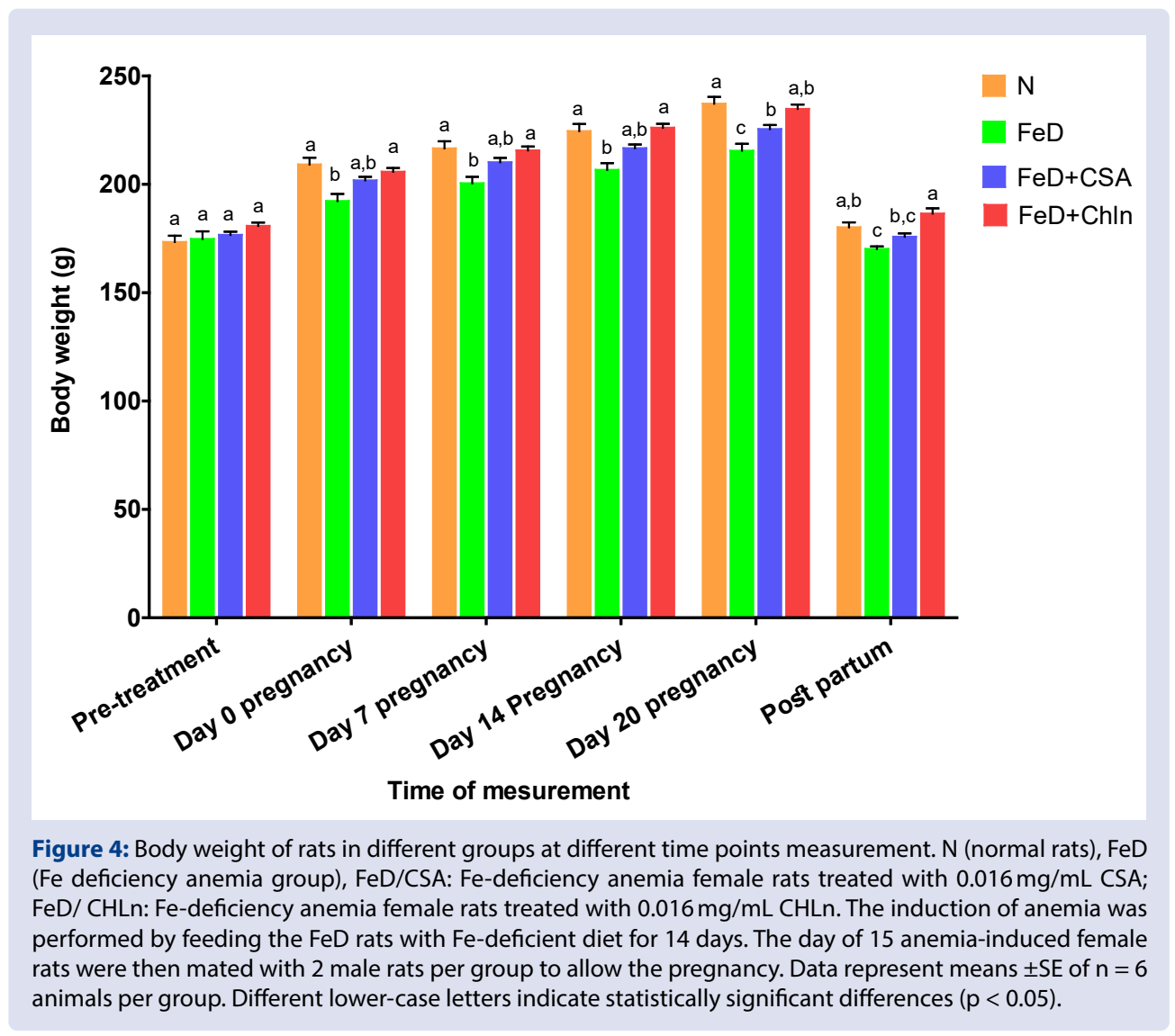


group which is in contrast with previous study where pretreatment with STZ was reported to attenuate pancreatic $\beta$-cell destruction due to the pancreas susceptibility to the alteration of antioxidant enzyme. ${ }^{28,30}$ The absence of a similar susceptibility of pancreatic cells after induced STZ suggests this effect may correlated with the irreversible effects of STZ on inducing hyperglycemia. ${ }^{30}$

As a positive control, diabetic rats were treated with glibenclamide, the most widely use antidiabetic drugs. This treatment caused substantial reduction in blood glucose levels in STZ-induced DM (Fig. 1) and showed significantly less degeneration score of hepatocytes, proximal tubule epithelium and pancreatic cells (Table 1). Glucose transport via GLUT1 protein was reported as the mechanism action of glibenclamide in reducing glucose and insulin levels in streptozotocin-induced rats. ${ }^{31}$

The similarity observed in the effect of reducing on the plasma glucose levels between diabetic rats treated with CSA and a treatment of commercial chlorophyllin are not surprising. These results are similar to those of our previous report in this strain of rats, where we showed that sodium nitrate-induced animals treated with CSA showed less lesion of hepatocytes and proximal tubule epithelium cells. ${ }^{19}$ Although the reduction of blood glucose levels of these treated animals was higher than those of treated with glibenclamide, our data suggest that the dose of $0.016 \mathrm{mg} / \mathrm{mL}$ CSA was sufficient to reduce blood glucose levels and cause low toxicity on liver, kidney and pancreas.

The hypoglycemic potential of CSA leaves found in the present study is substantiated bya similar responseobserved by Nissa etal.(2015), wherein the chlorophyll in papaya leaves exerted a significant hypoglycemic action in streptozotocin-induced diabetic rats. The chlorophyll extracts of the leaf have been postulated to have an antioxidative action. Other plant extracts like Trigonella foenumgraecum ${ }^{33}$, Anacardium occidentale $\mathrm{L}^{34}$ and extract of chlorophyll in papaya leaves ${ }^{32}$ have been reported as antidiabetic agents by increasing the body antioxidant status. Porphyrin is the essential structure of chlorophyll which supports its antioxidant action. $\mathrm{Mg}$ core plays an important role as a chelated form to support the activity. The mechanism of antioxidative action of chlorophyll is as a hydrogen donor to break the chain reaction, due to the porphyrin in its chemical structure. ${ }^{35}$

According to Taderegew et al. (2020) the chronic hyperglycemia of diabetes, especially when poorly controlled, causes an anemia. ${ }^{3}$ Ideally, we should use the same diabetic rats to see the relationship and the effectiveness of CSA to cure DM and anemia-related DM. However, in this study we studied separately as preliminary exploration of CSA to cure IDA.

Iron supplementation is the most method to improve maternal and birth outcomes in IDA during the pregnancy. ${ }^{36}$ Iron supplementation is reported as cheap and effective for IDA, however the supplement can cause great gastrointestinal irritation. ${ }^{37}$ Considering the high consumption of $S$. androgynus in Indonesia, we tried to explore chlorophyll from $S$. androgynus leaves (CSA) as a potential source to cure IDA in pregnant women. To prevent the side effects of consumption CSA as antianemia herbal supplement we observed the number of offspring and its body weight delivered form treated pregnant IDA rats. Our result support the previous study that showed CSA increased the level of hemoglobin ( $\mathrm{Hb})$, malondialdehyde (MDA), ferritin, and schistocytes percentage in anemia female mice induced by sodium nitrite..$^{38}$ Previously we also observed the potency of CSA compared to the commercial chlorophyll in anemia female rats induced by sodium nitrite. $^{19}$

In this study, we used the iron deficiency feed to induce anemia. The iron depletion causes the disturbance of oxygen transportation, deoxyribonucleic acid (DNA) synthesis, mitochondrial electron transport, and ultimately in the entire energy metabolism, which can trigger iron deficiency anemia (IDA) and body disfunction..$^{39}$ Consistent with previous findings, iron deficiency feed as indicated by a more than 2-fold decrease of hemoglobin levels, induced significant anemia within 14 days. ${ }^{24,40,41}$ At the end of the experiment (post-partum) the untreated IDA rats exhibited the lowest level of $\mathrm{Hb}$, serum iron and serum ferritin indicated that the anemia led the lack of iron intake still occurs. Moreover, the number of fetus and its body weight born form the IDA rats was significant different with control, as consistent with previous studies. ${ }^{8,24,42}$

Our results confirmed that supplementation with CSA could increase the level of $\mathrm{Hb}$, serum iron and serum ferritin. The serum iron and serum ferritin levels are considered as sensitive parameters of the iron status the blood circulation. ${ }^{40}$ In comparison with the Chln supplementation effect on the blood parameters, the same dose of CSA led to a better improvement. In addition, CSA supplement did not cause the reduction of offspring number and the body weight of the fetus, indicating that CSA is safe for pregnant woman with IDA.

\section{CONCLUSION}

This study has demonstrated that chlorophyll extract from Sauropus androgynus L. Merr leaves reduced the blood glucose level in streptozotocin-induced DM. The histological analysis of its toxicity in liver, kidney and pancreas can be used to select the most promising safety dose for subsequent human intervention. These results suggest that anemia was treated with CSA to increase the hemoglobin, ferritin and Fe. The toxicity in their offspring does not significantly different. Thus, CSA may be promising as therapeutic agents of DM and IDA. Further investigations must be conducted to investigate the biological and the toxicity effects of CSA as hypoglycemic and antianemia supplement.

\section{ACKNOWLEDGMENT}

This study was funded by Hibah Penelitian Kerjasama Antar Perguruan Tinggi (PEKERTI) from Ministry of Research, Technology and Higher Education Indonesia with contract Number No. 172/B.I/SA-LPPM/ IV/2015 at $20^{\text {th }}$ April 2015. The authors acknowledge to Research Development Unit, Faculty of Medicine Universitas Islam Sultan Agung, Semarang, Indonesia (contract number: 15/P-KEL/UPR-FK/ III/2016, 16/P-KEL/UPR-FK/III/2016，31/P-KEL/UPR-FK/IX/2016, 34/P-KEL/UPR-FK/IX/2016) for supporting this research.

\section{CONFLICTS OF INTEREST}

No potential conflicts of interest was reported by the authors.

\section{REFERENCES}

1. WHO. Guidelines on Second-And Third-Line Medicines and Type of Insulin for the Control of Blood Glucose Levels in Non-Pregnant Adults with Diabetes Mellitus.; 2018. https://www.who.int/publications/i/ item/guidelines-on-second--and-third-line-medicines-and-type-ofinsulin-for-the-control-of-blood-glucose-levels-in-non-pregnant-adultswith-diabetes-mellitus

2. Kemenkes-RI. Laporan Nasional Riskesdas 2018.; 2019. http:// labdata.litbang.kemkes.go.id/images/download/laporan/RKD/2018/ Laporan_Nasional_RKD2018_FINAL.pdf

3. Taderegew MM, Gebremariam T, Tareke AA, Woldeamanuel GG Anemia and Its Associated Factors Among Type 2 Diabetes Mellitus Patients Attending Debre Berhan Referral Hospital, North-East Ethiopia: A Cross-Sectional Study. J Blood Med. 2020;11:47-58. doi:10.2147/JBM.S243234

4. Antwi-Bafour S, Hammond S, Adjei JK, Kyeremeh R, Martin-Odoom A, Ekem I. A case-control study of prevalence of anemia among patients with type 2 diabetes. J Med Case Rep. 2016;10(1):110. doi:10.1186/s13256-016-0889-4

5. WHO. Nutritional Anaemias: Tools For Effective Prvention and Control. WHO; 2017. https://www.who.int/publications/i/item/9789241513067 
6. WHO. Anaemia.; 2020. Accessed September 25, 2020. https://www. who.int/health-topics/anaemia\#tab=tab_1

7. Kemenkes-RI. Profil Kesehatan Indonesia Tahun 2019.; 2020. https:// www.kemkes.go.id/resources/download/pusdatin/profil-kesehatanindonesia/Profil-Kesehatan-Indonesia-2019.pdf

8. Saloojee H, Pettifor JM. Iron deficiency and impaired child development. BMJ. 2001;323(7326):1377-1378. doi:10.1136/ bmj.323.7326.1377

9. Choudhury $H$, Pandey $M$, Hua $C K$, et al. An update on natural compounds in the remedy of diabetes mellitus: A systematic review. J Tradit Complement Med. Published online 2018:361-376. doi:10.1016/j.jtcme.2017.08.012

10. Anosike CA, Igboegwu ON, Nwodo OFC. Antioxidant properties and membrane stabilization effects of methanol extract of Mucuna pruriens leaves on normal and sickle erythrocytes. J Tradit Complement Med. 2019;9(4):278-284. doi:10.1016/j.jtcme.2017.08.002

11. Sa'roni S, Sadjiman T, Sja'bani M, Zulaela Z. Effectiveness Of The Sauropus Androgynus (L.) Merr Leaf Extract In Increasing Mother's Breast Milk Production. Media Penelit dan Pengemb Kesehat. 2004;14(3). doi:10.22435/mpk.v14i3 Sept.903.

12. Soka S, Alam H, Boenjamin N, Agustina TW, Suhartono MT. Effect of Sauropus androgynus Leaf Extracts on the Expression of Prolactin and Oxytocin Genes in Lactating BALB/C Mice. J Nutrigenet Nutrigenomics. 2010;3(1):31-36. http://www.karger.com/ DOI/10.1159/000319710

13. Khoo HE, Azlan A, Ismail A. Sauropus androgynus leaves for health benefits: Hype and the science. Nat Prod J. 2015;5(2):115-123. doi:10 .2174/221031550502150702142028

14. Bunawan H, Bunawan SN, Baharum SN, Noor NM. Sauropus androgynus (L.) Merr. Induced Bronchiolitis Obliterans: From Botanical Studies to Toxicology. Evidence-Based Complement Altern Med. 2015;2015:7. doi:10.1155/2015/714158

15. Xiao C, Lei XG, Wang QY, et al. Effects of a Tripeptide Iron on IronDeficiency Anemia in Rats. Biol Trace Elem Res. 2016;169(2):211-217. doi:10.1007/s12011-015-0412-6

16. Yunita O, Yuwono M, Rantam FA. In vitro cytotoxicity assay of Sauropus androgynus on human mesenchymal stem cells. Toxicol Environ Chem. 2013:95(4):679-686. doi:10.1080/02772248.2013.798412

17. Sai KS, Srividya N. Blood glucose lowering effect of the leaves of Tinospora cordifolia and Sauropus androgynus in diabetic subjects. J Nat Remedies. 2002;2(1):28-32. doi:10.18311/jnr/2002/341

18. Suparmi S, Sampurna S, Nur Anna CS, et al. Anti-anemia effect of chlorophyll from katuk (sauropus androgynus) leaves on female mice induced sodium nitrite. Pharmacogn J. 2016;8(4). doi:10.5530/ pj.2016.4.10

19. Suparmi S, Fasitasari M, Martosupono M, Mangimbulude JC. Comparisons of Curative Effects of Chlorophyll from Sauropus androgynus (L) Merr Leaf Extract and Cu-Chlorophyllin on Sodium Nitrate-Induced Oxidative Stress in Rats. J Toxicol. 2016;2016. doi:10.1155/2016/8515089

20. Piao Y, Liu Y, Xie X. Change Trends of Organ Weight Background Data in Sprague Dawley Rats at Different Ages. J Toxicol Pathol. 2013;26(1):29-34. doi:10.1293/tox.26.29

21. Ishak K, Baptista $A$, Bianchi $L$, et al. Histological grading and staging of chronic hepatitis. J Hepatol. Published online 1995. doi:10.1016/01688278(95)80226-6

22. Tan P V, Mezui C, Enow-Orock G, Nijkam N, Dimo T, Bitolog P. Teratogenic effects, acute and sub chronic toxicity of the leaf aqueous extract of Ocimum suave Wild (Lamiaceae) in rats. J Ethnopharmacol. 2008;115(2):232-237. doi:10.1016/j.jep.2007.09.022

23. Nurdiana S, Goh YM, Ahmad H, et al. Changes in pancreatic histology, insulin secretion and oxidative status in diabetic rats following treatment with Ficus deltoidea and vitexin. BMC Complement Altern Med. 2017;17(1):290. doi:10.1186/s12906-017-1762-8

24. Zhang X-G, Wei G-X, Wang W-N, Ma G-D, Tang P, Chen X-Q. Effects of Fe-YM1504 on iron deficiency anemia in rats. Food Funct. 2016;7(7):3184-3192. doi:10.1039/C6FO00423G

25. Bosman DR, Winkler AS, Marsden JT, Macdougall IC, Watkins PJ. Anemia With Erythropoietin Deficiency Occurs Early in Diabetic Nephropathy. Diabetes Care. 2001;24(3):495 LP - 499. doi:10.2337/ diacare.24.3.495
26. Rani PK, Raman R, Rachepalli SR, et al. Anemia and diabetic retinopathy in type 2 diabetes mellitus. J Assoc Physicians India. Published online 2010.

27. Kakkar R, Mantha S V., Radhi J, Prasad K, Kalra J. Increased oxidative stress in rat liver and pancreas during progression of streptozotocininduced diabetes. Clin Sci. Published online 1998. doi:10.1042/ cs0940623

28. Roza AM, Pieper GM, Johnson CP, Adams MB. Pancreatic Antioxidant Enzyme Activity in Normoglycemic Diabetic Prone BB Rats. Pancreas. 1995;10(1). https://journals.Iww.com/pancreasjournal/ Fulltext/1995/01000/Pancreatic_Antioxidant_Enzyme_Activity_ in.7.aspx

29. Knight TR, Fariss MW, Farhood A, Jaeschke H. Role of Lipid Peroxidation as a Mechanism of Liver Injury after Acetaminophen Overdose in Mice. Toxicol Sci. 2003;76(1):229-236. doi:10.1093/ toxsci/kfg220

30. Zafar M, Naeem-ul-Hassan Naqvi S. Effects of STZ-Induced Diabetes on the Relative Weights of Kidney, Liver and Pancreas in Albino Rats: A Comparative Study. Int J Morphol. Published online 2010. doi:10.4067/s0717-95022010000100019

31. Sokolovska J, Isajevs S, Sugoka O, et al. Comparison of the effects of glibenclamide on metabolic parameters, GLUT1 expression, and liver injury in rats with severe and mild streptozotocin-induced diabetes mellitus. Med. Published online 2012. doi:10.3390/medicina48100078

32. Nissa C, Kartasurya MI, Rahmawati B. Effects of Chlorophyll in Papaya Leaves on Superoxide Dismutation and Blood Glucose Level of Diabetic Rats. Makara J Heal Res. 2015;19(2):75-80. doi:10.7454/ mjhr.v19i2.5179

33. Pradeepkiran JA, Nandyala VS, Bhaskar M. Trigonella foenumgraecum seeds extract plays a beneficial role on brain antioxidant and oxidative status in alloxan-induced Wistar rats. Food Qual Saf. Published online May 8, 2020. doi:10.1093/fqsafe/fyaa015

34. Jaiswal YS, Tatke PA, Gabhe SY, Vaidya AB. Antidiabetic activity of extracts of Anacardium occidentale Linn. leaves on n-streptozotocin diabetic rats. J Tradit Complement Med. 2017;7(4):421-427. doi:10.1016/j.jtcme.2016.11.007

35. Endo Y, Usuki R, Kaneda T. Antioxidant effects of chlorophyll and pheophytin on the autoxidation of oils in the dark. II. The mechanism of antioxidative action of chlorophyll. J Am Oil Chem Soc. 1985;62(9):1387-1390. doi:10.1007/BF02545965

36. Peña-Rosas JP, De-Regil LM, Garcia-Casal MN, Dowswell T. Daily oral iron supplementation during pregnancy. Cochrane Database Syst Rev. Published online 2015. doi:10.1002/14651858.CD004736.pub5

37. Tolkien Z, Stecher L, Mander AP, Pereira DIA, Powell JJ. Ferrous sulfate supplementation causes significant gastrointestinal sideeffects in adults: A systematic review and meta-analysis. PLoS One. 2015;10(2). doi:10.1371/journal.pone.0117383

38. Suparmi S, Sampurna S, Nur Anna CS, et al. Anti-anemia Effect of Chlorophyll from Katuk (Sauropus androgynus) Leaves on Female Mice Induced Sodium Nitrite. Pharmacogn J. 2016;8(4). doi:10.5530/ pj.2016.4.10

39. Conrad ME, Umbreit JN. Iron absorption and transport-An update. Am J Hematol. 2000;64(4):287-298. doi:10.1002/10968652(200008)64:4<287::AID-AJH9>3.0.CO;2-L

40. He H, Huang $\mathrm{Q}$, Liu C, et al. Effectiveness of AOS-iron on iron deficiency anemia in rats. RSC Adv. 2019;9(9):5053-5063. doi:10.1039/ C8RA08451C

41. Matsumoto $N$, Ikeda $H$, Shigefuku R, et al. Hemoglobin decrease with iron deficiency induced by daclatasvir plus asunaprevir combination therapy for chronic hepatitis c virus genotype $1 \mathrm{~b}$. PLoS One. 2016;11(3). doi:10.1371/journal.pone.0151238

42. Akin M, Sarbay H, Guler S, Balci YI, Polat A. Response to parenteral iron therapy distinguish unexplained refractory iron deficiency anemia from iron-refractory iron deficiency anemia. Int J Lab Hematol. 2016;38(2):167-171. doi:10.1111/ijlh.12462 


\section{GRAPHICAL ABSTRACT}

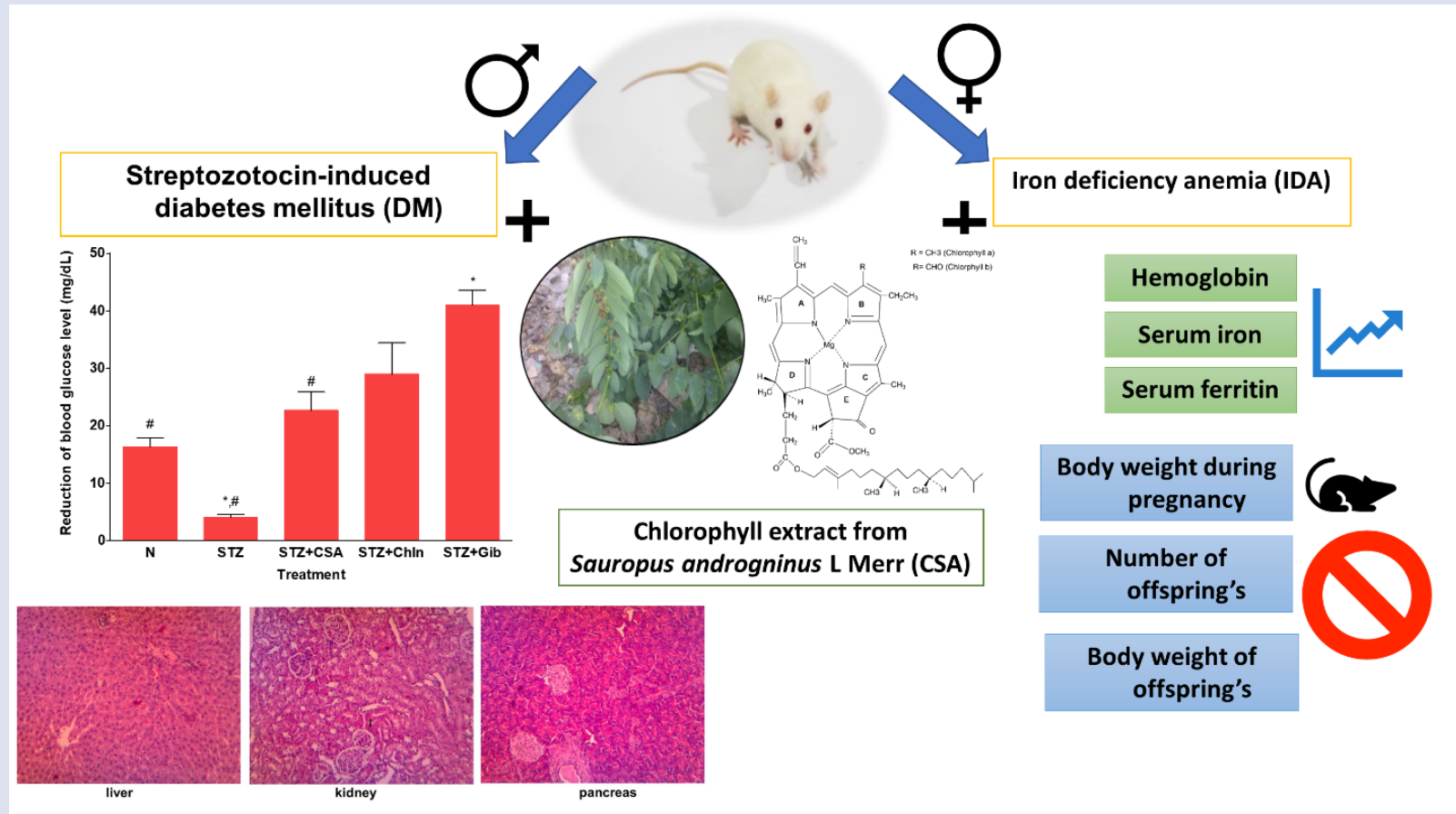

\section{SUMMARY}

- Hypoglycaemic and antianemia effects of chlorophyll from Sauropus androgninus (CSA) were investigated in rats.

- CSA decreases the levels of blood glucose levels in streptozotocin-induced diabetes mellitus (DM)

- CSA increases the levels of haemoglobin, serum iron, and serum ferritin in iron deficiency anaemia (IDA) rats.

- CSA is a potential new herbal supplement to cure DM and IDA.

\section{ABOUT AUTHORS}

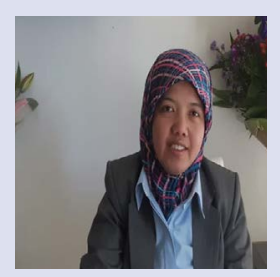

Suparmi is an Assistant Professor at the Department of Biology, Faculty of Medicine, Universitas Islam Sultan Agung, Semarang, Indonesia. After graduated her PhD study at Division of Toxicology, Wageningen University and Research, The Netherlands in April 2020, she is being a guest Postdoc at the same institution. Her project is about Risk and benefit analysis of herbal products from Indonesia.

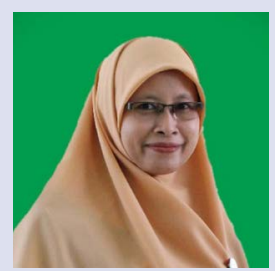

Minidian Fasitasari is an Assistant Professor at the Department of Clinical Nutrition, Faculty of Medicine, Universitas Islam Sultan Agung, Semarang, Indonesia. Currently, she is a Director of Education, Sultan Agung Islamic Hospital, Semarang, Indonesia. 


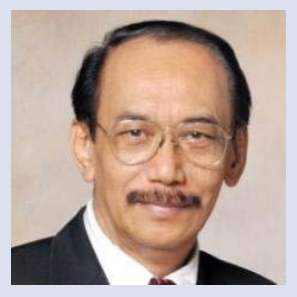

Martanto Martosupono is a pensionary Associate Professor at Master Program of Biology, Satya Wacana Christian University, Indonesia. His expertise is on natural products from plant pigments and teas.

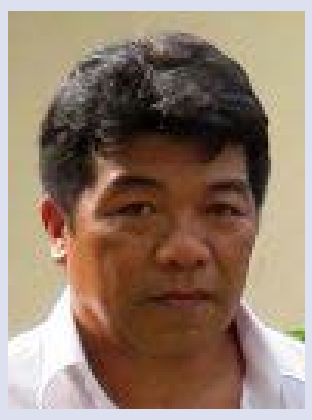

Jubhar Christian Mangimbulude is an Assistant Professor at the Master Program of Biology, Satya Wacana Christian University, Indonesia. Currently he is working at the Faculty of Theology, Halmahera University, Indonesia.

Cite this article: Suparmi S, Fasitasari M, Martosupono M, Mangimbulude JC. Hypoglycemic and Antianemia Effects of Chlorophyll from Sauropus androgynus (L) Merr Leaves in Rats. Pharmacog J. 2021;13(4): 924-932. 